\title{
PENGARUH RELIGIOSITAS DAN KONFORMITAS TEMAN SEBAYA TERHADAP PERILAKU PROSOSIAL MAHASISWA YANG MENGIKUTI PERSEKUTUAN
}

\author{
Chiquitita Agnita $^{1}$ \& Selviana ${ }^{2}$ \\ Indonesia \\ Korespondensi: \\ ${ }^{1}$ e-mail: chiquiagnita@gmail.com; ${ }^{2}$-mail:selvi.humble@gmail.com
}

Fakultas Psikologi Universitas Persada Indonesia YAI, Jalan Diponegoro No. 74, Jakarta Pusat 10430,

\begin{abstract}
This study aims to determine the effect of religiosity and peer conformity on prosocial behavior. Respondents in this study consisted of 72 students who participated in Christian spiritual fellowship (Perkantas). Data were collected using the scale of prosocial behavior, scale of religiosity and scale of peer conformity; all were particularly developed by the researchers. The results revealed that there are partial and simultan effects of religiosity and peer conformity on prosocial behavior. It was concluded that religiosity and peer conformity have an important role in shaping prosocial behavior in everyday life.
\end{abstract}

Article history:

Received 8 January 2019

Received in revised form 15 February 2019

Accepted 19 August 2019

Available online 13 September 2019

Keywords:

conformity with peers;

prosocial behavior;

religiosity

\begin{abstract}
Abstrak - Penelitian ini bertujuan untuk mengetahui pengaruh religiositas dan konformitas teman sebaya terhadap perilaku prososial. Responden penelitian adalah mahasiswa-mahasiswi yang mengikuti persekutuan rohani Kristen Perkantas berjumlah 72 orang. Pengumpulan data dengan menggunakan skala perilaku prososial, skala religiositas, dan skala konformitas teman sebaya yang dikembangkan peneliti. Hasil penelitian membuktikan bahwa terdapat pengaruh secara parsial maupun pengaruh secara simultan religiositas dan konformitas teman sebaya terhadap perilaku prososial. Dengan demikian, dapat disimpulkan bahwa religiositas dan konformitas teman sebaya berperan penting dalam membentuk perilaku prososial dalam kehidupan sehari-hari.
\end{abstract}

Kata Kunci: konformitas teman sebaya; perilaku prososial; religiositas 


\section{PENDAHULUAN}

Indonesia dikenal sebagai negara dengan budaya kolektif yang mengutamakan kepentingan bersama atau kelompoknya dibandingkan kepentingan pribadi. Dengan kata lain, budaya kolektif ini mengedepankan perilaku saling menolong. Perilaku saling menolong dalam ilmu psikologi disebut dengan perilaku prososial. Perilaku prososial merupakan perilaku menolong yang bermotif positif, sehingga menjadi perilaku yang bermanfaat dan dimaksudkan untuk mengembangkan penerimaan sosial, serta persahabatan (Baron \& Byrne, 2005).

Myers (1999) berpendapat bahwa perilaku prososial dapat timbul karena dipengaruhi oleh situasi atau keadaan, yaitu keadaan yang dapat mendorong seseorang untuk memberikan bantuan dalam keadaan darurat, seperti menolong korban bencana alam, mendonorkan darah, maupun memberikan bantuan pada orang yang sedang mengalami kesulitan.

Hal ini membuat perilaku prososial berperan besar dalam mengubah perilaku seseorang yang awalnya tidak tergerak untuk memberikan pertolongan, mengubah perilakunya dengan turut memberikan pertolongan karena adanya rasa kemanusiaan untuk saling menolong dan peduli terhadap sesama. Dalam hal ini, usaha yang dilakukan satu orang atau lebih untuk mengubah sikap, kepercayaan, persepsi, atau perilaku dari orang lain dinamakan konformitas (Baron \& Byrne, 2005).

Konformitas berkaitan dengan rasa pertemanan yang kuat, sehingga membuat seseorang bersedia untuk dapat memenangkan persetujuan teman sebaya dan mendapatkan popularitas (Papalia, Olds, \& Feldman, 2013). Konformitas dengan teman sebaya berakar pada persepsi eksplisit maupun implisit yang mengindikasikan bagaimana seseorang sebaiknya berperilaku di dalam kelompok. Norma sosial yang berlaku di dalam kelompok teman sebaya akan menimbulkan efek yang kuat terhadap perilaku seseorang.

Hasil penelitian mengenai konformitas teman sebaya terhadap perilaku remaja menyatakan bahwa konformitas dengan teman sebaya cukup banyak memengaruhi perilaku negatif pada remaja, seperti perilaku konsumerisme (Suryadi, 2009), perilaku menunda akademik (Cinthia \& Kustanti, 2017), perilaku menyontek (Wicaksono \& Andriani, 2015), dan kenakalan remaja lainnya (Karvani \& Nangoi, 2013).

Konformitas dapat membawa pengaruh buruk (ketika seseorang dalam kondisi mabuk atau dalam berkendara), pengaruh baik (ketika seseorang hendak menghalangi orang-orang yang hendak memotong antrian di teater), atau pengaruh yang tidak jelas (ketika menggunakan kaos berwarna putih saat bermain tenis) (Myers, 1999). Dengan kata lain, seseorang dapat melakukan konformitas 
bergantung pada situasi yang sedang dihadapinya. Hal ini juga dibuktikan oleh penelitian Pertiwi dan Masykur (2014) yang menunjukkan bahwa terdapat hubungan positif antara konformitas dengan intensi prososial pada remaja warga binaan pemasyarakatan lapas anak. Hal lain yang turut memberikan efek kuat pada perilaku seseorang adalah norma agama (religiositas).

Pentingnya religiositas dalam kehidupan seseorang dalam berperilaku juga didukung dari hasil penelitian Carlo dan Hardy (2005) yang mengemukakan bahwa religiositas adalah potensi positif dalam meningkatkan perilaku yang cenderung memberi kontribusi kebaikan atau kesejahteraan kepada orang lain. Pernyataan ini menegaskan bahwa religiositas berfungsi secara positif terhadap peningkatan perilaku seseorang, sehingga dapat membuat orang tersebut melakukan kebaikan dalam kehidupannya sehari-hari.

Lebih lanjut, Campbell (dalam Baron \& Byrne, 2005) menyatakan bahwa individu yang religius juga dapat menahan diri untuk menolong jika mengatribusikan tanggung jawab tersebut pada korban. Jika korban dipersepsikan sebagai seorang yang berseberangan dengan nilai-nilai religius yang ada (misalnya, mabuk karena alkohol), maka individu tersebut cenderung untuk tidak menolong. Hal ini menunjukkan bahwa ada banyak faktor yang dapat memengaruhi perilaku prososial, yaitu berdasarkan situasi yang ada dan pertimbangan lain dari dalam diri secara pribadi yang turut memengaruhi seseorang dalam berperilaku prososial.

Konformitas dengan teman sebaya juga terlihat dari kehidupan mahasiswa. Mahasiswa umumnya sedang berada dalam usia remaja akhir sampai dewasa awal, yaitu berusia 18-24 tahun. Sears dkk. (1988) menyatakan bahwa mahasiswa berada pada usia 18-40 tahun atau masa dewasa awal yang merupakan periode penyesuaian diri terhadap pola-pola kehidupan, serta harapanharapan sosial yang baru. Itulah sebabnya, selain berkuliah, mahasiswa dipenuhi keinginan untuk mengikuti banyak aktivitas dalam berbagai komunitas sosial yang membuatnya dekat dengan konformitas teman sebaya, seperti komunitas-komunitas di kampus, komunitas hobi, maupun komunitas kerohanian atau disebut persekutuan bagi mahasiswa Kristen.

Persekutuan Kristen Antar Universitas (Perkantas) secara rutin dilakukan seminggu sekali, baik persekutuan dalam kelompok besar maupun dalam kelompok kecil yang secara khusus terpanggil untuk melayani dan menjadi pengurus di persekutuan tersebut, serta diberi tanggung jawab untuk mengelola persekutuan. Mahasiswa yang mengikuti persekutuan ini berasal dari latar belakang yang berbeda-beda, seperti berbeda jurusan kuliah, kampus, dan angkatan. Namun, dalam persekutuan ini mahasiswa belajar untuk mengalami kasih Tuhan, saling mendukung sebagai 
mahasiswa seiman, belajar untuk saling menguatkan saat mengalami permasalahan hidup, dan belajar untuk senantiasa berbuat baik pada sesama (perilaku prososial).

Penelitian King dan Forruw (2004) menyatakan bahwa dari 50,000 remaja di 60 negara, sebanyak 87 persen responden merupakan bagian dari suatu keyakinan agama tertentu, 63 persen menunjukkan bahwa Tuhan sangat penting dalam kehidupannya, dan 75 persen percaya pada Tuhan secara pribadi. Selain itu, King dan Furrow juga menyatakan bahwa dengan adanya berbagai pihak terdekat, seperti orang tua dan teman, dapat berperan penting dalam memediasi terbentuknya perilaku yang baik bagi remaja. Penelitian lainnya juga dikemukakan oleh Lim dan Putnam (2010) yang menunjukkan bahwa religiositas dapat memberikan kepuasan hidup melalui jaringan sosial atau hubungan baik yang terjalin dengan sesama manusia. Dengan kata lain, seseorang yang religius membutuhkan sesamanya untuk saling mengasihi, saling membantu, dan memperoleh kepuasan hidup.

Merujuk pada hasil-hasil penelitian tersebut, maka perilaku prososial mahasiswa yang mengikuti persekutuan ini menjadi penting untuk diteliti lebih lanjut karena mahasiswa yang mengikuti persekutuan belajar tentang nilai-nilai mengasihi Tuhan dan sesama yang dalam aplikasinya terlihat pada perilakunya di kehidupan sehari-hari. Selain itu, para mahasiswa yang tergolong anak-anak muda ini cenderung berperilaku tertentu dikarenakan adanya konformitas dari pergaulan atau teman-temannya, sehingga peneliti tertarik untuk mengadakan penelitian mengenai pengaruh religiositas dan konformitas teman sebaya terhadap perilaku prososial mahasiswa yang mengikuti Persekutuan Kristen Antar Universitas (Perkantas) di Jakarta.

\section{Pengaruh Religiositas terhadap Perilaku Prososial}

Perilaku prososial dipengaruhi beberapa aspek yang ada pada diri individu, salah satunya adalah religiositas. Penelitian Carlo dan Hardy (2005) menyatakan adanya pengaruh religiositas terhadap perilaku prososial yang dimediasi oleh variabel kebaikan (kindness). Hasil penelitian ini menunjukkan bahwa religiositas seseorang tercermin dalam perilaku-perilaku nyata yang berdampak positif bagi dirinya dan sesama. Sedangkan, Zubaidi (2009) mengungkapkan bahwa religiositas adalah kepekaan dan penghayatan seseorang akan hubungannya yang dekat dengan Tuhan, sesama manusia, dan lingkungan sekitarnya yang diungkap secara lahiriah dalam bentuk pengamalan ajaran agama yang diyakininya. Pengertian ini mengacu pada penghayatan seseorang akan suatu hubungan yang dalam dengan Tuhan dan sesama. Dalam penelitiannya, Zubaidi menjadikan religiositas (kesadaran religius) sebagai komponen intrapsikis dalam berperilaku. 
Mahasiswa yang mengikuti persekutuan Kristen antar universitas menerima pembinaan secara rohani, di mana nilai-nilai kekristenan diaplikasikan dalam kehidupan. Salah satu nilai yang diajarkan adalah dengan mengasihi Tuhan dan sesama manusia yang membutuhkan pertolongan (prososial).

\section{Pengaruh Konformitas Teman Sebaya terhadap Perilaku Prososial}

Konformitas merupakan perilaku seseorang sebagai usaha untuk menyesuaikan diri dengan norma kelompok, baik ada maupun tidak ada tekanan secara langsung yang berupa suatu tuntutan tidak tertulis dari teman-teman sebaya terhadap mahasiswa yang umumnya sedang mengembangkan persahabatan yang lebih intim dengan teman-teman sebayanya. Di sisi lain, relasi pertemanan semakin luas, baik dengan teman-teman sebaya di kelas atau perkuliahannya.

Konformitas memengaruhi berbagai aspek dalam kehidupan mahasiswa, seperti aktivitas di kampus, kegiatan akademik, aktivitas sosial yang akan diikuti, penampilan, bahasa yang digunakan, serta nilai-nilai maupun perilaku yang dianut dan dipandang baik, serta dilakukan oleh kelompok tersebut. Penelitian oleh Pradana (2013) menunjukkan adanya hubungan positif yang sangat signifikan antara konformitas dengan altruisme (sifat yang lebih mengutamakan kepentingan orang lain). Artinya, semakin tinggi tingkat konformitas seseorang, maka semakin tinggi pula tingkat altruismenya. Kehadiran teman-teman sebaya turut memengaruhi perilaku prososial. Hal ini disebabkan karena kelompok teman sebaya tersebut juga menganggap baik dan menerapkan perilaku prososial tersebut di dalam kelompoknya. Pengaruh konformitas teman sebaya juga dapat memengaruhi perilaku prososial ketika seseorang yang semula tidak berniat untuk memberi sumbangan atau bantuan kepada teman yang tertimpa musibah, akan berubah pikiran dan mengikuti teman-teman sebayanya yang telah memberikan sumbangan dengan alasan kemanusiaan, kekompakkan, persatuan dan kebersamaan, serta alasan lainnya. Dengan demikian, dapat dikatakan bahwa terdapat pengaruh konformitas teman sebaya terhadap perilaku prososial.

Berdasarkan uraian di atas, dapat disimpulkan bahwa religiositas dan konformitas teman sebaya diduga dapat memengaruhi terjadinya perilaku prososial pada mahasiswa yang mengikuti Persekutuan Kristen Antar Universitas (Perkantas) Jakarta.

\section{Hipotesis}

Berdasarkan kerangka berpikir yang telah diuraikan, maka hipotesis yang diajukan dalam penelitian ini adalah sebagai berikut. 
Hipotesis 1: Ada pengaruh antara religiositas terhadap perilaku prososial mahasiswa yang mengikuti Persekutuan Kristen Antar Universitas (Perkantas) Jakarta.

Hipotesis 2: Ada pengaruh antara konformitas dengan teman sebaya terhadap perilaku prososial mahasiswa yang mengikuti Persekutuan Kristen Antar Universitas (Perkantas) Jakarta.

Hipotesis 3: Ada pengaruh antara religiositas dan konformitas dengan teman sebaya secara bersama-sama terhadap perilaku prososial mahasiswa yang mengikuti Persekutuan Kristen Antar Universitas (Perkantas) Jakarta.

\section{METODE}

\section{Partisipan}

Populasi dalam penelitian ini adalah mahasiswa-mahasiswi Kristen yang menjadi pengurus persekutuan siswa dan persekutuan mahasiswa Perkantas Jakarta. Mahasiswa yang menjadi pengurus persekutuan siswa berjumlah 43 orang dan mahasiswa yang menjadi pengurus persekutuan mahasiswa berjumlah 29 orang. Dengan demikian, total keseluruhan populasi adalah 72 orang. Teknik sampling dalam penelitian ini adalah sampling jenuh atau sensus (non probability sampling) dikarenakan jumlah populasi cukup terbatas, sehingga masih memungkinkan apabila semua populasi diikutkan dalam penelitian. Sebanyak 30 orang digunakan untuk uji validitas dan reliabilitas instrumen penelitian dan sebanyak 42 orang sebagai responden penelitian.

\section{Desain}

Penelitian ini menggunakan metode penelitian kuantitatif yang ingin melihat pengaruh langsung dan signifikansinya pada variabel bebas terhadap variabel terikat.

\section{Prosedur}

Pengumpulan data dengan menggunakan kuesioner yang dikembangkan sendiri oleh peneliti. Kuesioner menggunakan skala model Likert dengan rentang 1-5 (Sangat Sesuai, Sesuai Cukup Sesuai, Tidak Sesuai, dan Sangat Tidak Sesuai) yang semua butirnya disusun sendiri oleh penulis.

Penyusunan skala perilaku prososial berdasarkan aspek-aspek Mussen (dalam Khoirina, 2015), yaitu berbagi, kerja sama, menolong, berlaku jujur, dan bersedekah. Skala ini terdiri dari 32 
butir pernyataan yang terbagi atas 16 butir favorable dan 16 butir unfavorable. Contoh butir: 'Saya merasa bahagia dengan membantu sesama yang mengalami kesulitan'.

Penyusunan skala religiositas berdasarkan dimensi-dimensi Glock (dalam Sinaga, 2015), yaitu keyakinan, peribadatan, penghayatan, pengetahuan, dan pengalaman. Skala ini terdiri dari 32 butir pernyataan yang terbagi atas 16 butir favorable dan 16 butir unfavorable. Contoh butir: 'Saya senang mendoakan orang lain'.

Penyusunan skala konformitas teman sebaya berdasarkan aspek-aspek Sears dkk. (1988), yaitu kekompakan, kesepakatan, dan ketaatan. Skala ini terdiri dari 25 butir pernyataan yang terbagi atas 12 butir favorable dan 13 butir unfavorable. Contoh butir: 'Kelompok saya mendorong untuk senantiasa berbuat baik bagi sesama’.

Setelah instrumen penelitian dibuat, selanjutnya dilakukan pengujian validitas dan reliabilitasnya guna mengetahui apakah instrumen ini layak digunakan untuk mengukur atributatribut dalam penelitian ini. Dari hasil uji validitas skala perilaku prososial, sebanyak 7 butir dinyatakan gugur dan 25 butir lainnya dinyatakan valid $(\alpha=.862)$. Hasil uji validitas skala religiositas mendapati 1 butir dinyatakan gugur dan 31 butir lainnya dinyatakan valid $(\alpha=.865)$. Dari hasil uji validitas skala konformitas teman sebaya, terdapat 8 butir yang dinyatakan gugur dan 17 butir lainnya dinyatakan valid $(\alpha=.609)$. Setelah dilakukan uji validitas, maka analisis data dapat dilakukan.

\section{Teknik Analisis}

Teknik analisis penelitian ini menggunakan statistik inferensial parametris, yaitu dengan analisis regresi dan uji komparatif dengan analisis $t$-test. Seluruh analisis data dalam penelitian ini dilakukan dengan program SPSS for windows.

\section{ANALISIS DAN HASIL}

Responden dalam penelitian ini didominasi oleh perempuan (60\%) dengan rentang usia bervariasi, mulai dari usia 16-18 tahun (19\%), 19-22 tahun (71\%), dan 23-25 tahun (10\%). Hasil uji Independent Sample T-Test menunjukkan bahwa perempuan $(M=91.280)$ lebih cenderung berperilaku prososial daripada laki-laki $(M=83.647$; $t=-.244 ; p=.337)$. 


\section{Pengujian Hipotesis 1}

Berdasarkan hasil analisis regresi terhadap hipotesis pertama, ditemukan bahwa religiositas secara parsial berpengaruh signifikan terhadap perilaku prososial $(t=5.497 ; p=<.05)$. Lebih lanjut, kontribusi religiositas terhadap perilaku prososial adalah 61.6 persen.

\section{Pengujian Hipotesis 2}

Berdasarkan hasil analisis regresi terhadap hipotesis kedua, ditemukan bahwa konformitas teman sebaya secara parsial berpengaruh signifikan terhadap perilaku prososial $(t=3.193$; $p=<$ .05). Kontribusi konformitas teman sebaya terhadap perilaku prososial adalah 45.9 persen.

\section{Pengujian Hipotesis 3}

Religiositas dan konformitas teman sebaya secara simultan atau bersama-sama berpengaruh signifikan terhadap perilaku prososial $(F=44.514 ; p=<.05)$. Kontribusi religiositas dan konformitas teman sebaya terhadap perilaku prososial adalah 69.5 persen.

\section{DISKUSI}

Berdasarkan hasil analisis data terhadap uji hipotesis pertama yang telah diuraikan sebelumnya, terbukti bahwa adanya pengaruh yang signifikan antara religiositas terhadap perilaku prososial mahasiswa yang mengikuti Persekutuan Mahasiswa Kristen Antar Universitas (Perkantas) Jakarta. Dengan demikian, penelitian ini menunjukkan bahwa religiositas, termasuk yang dibangun dalam persekutuan mahasiswa, dapat mendorong mahasiswa untuk lebih berperilaku prososial. Hal ini menunjukkan bahwa semakin tinggi religiositas mahasiswa, semakin tinggi perilaku prososialnya. Temuan ini selaras dengan penelitian Sinaga (2015) yang menyatakan bahwa terdapat hubungan yang positif dan signifikan antara religiositas dengan perilaku prososial, sehingga semakin tinggi tingkat religiositas seseorang, semakin tinggi pula kecenderungan untuk berperilaku prososial.

Religiositas merupakan suatu bentuk hubungan manusia dengan Penciptanya melalui ajaran agama yang terinternalisasi dalam diri seseorang dan tercermin dalam perilakunya sehari-hari (Carlo \& Hardy, 2005). Hal ini dapat mendorong seseorang untuk melakukan kebaikan kepada sesama, sesuai yang diajarkan dalam keyakinan agamanya agar memiliki sikap yang lebih manusiawi, toleran, saling mengasihi, dan saling menolong. Dengan kata lain, seseorang yang 
memiliki relasi dekat dengan Tuhan dan mengimplementasikan nilai-nilai keagamaannya dalam hidup akan cenderung lebih menunjukkan perilaku prososial dalam kehidupannya sehari-hari. Pernyataan ini senada dengan pandangan Zubaidi (2009) yang menyatakan bahwa faktor religiositas memengaruhi seseorang untuk mengaplikasikan ajaran-ajaran agamanya dalam hal menolong atau berbuat baik. Dengan kata lain, ada dasar nilai-nilai keagamaan yang mengajarkan tentang kebaikan yang membuat seseorang mau mengasihi sesamanya dengan ketulusan, bukan malah sebaliknya.

Berdasarkan hasil analisis data terhadap uji hipotesis kedua yang telah diuraikan sebelumnya, terbukti bahwa ada pengaruh yang signifikan antara konformitas teman sebaya terhadap perilaku prososial mahasiswa yang mengikuti Persekutuan Mahasiswa Kristen Antar Universitas (Perkantas) Jakarta. Hal ini sejalan dengan penelitian Pertiwi dan Masykur (2014) yang menunjukkan bahwa terdapat hubungan positif antara konformitas dengan intensi prososial. Sebagai mahkluk sosial, individu akan bergabung dengan kelompok yang memiliki kesamaan pandangan dan mendorongnya untuk menampilkan perilaku tertentu. Dalam hal ini, mahasiswa yang tergabung dalam kelompok Persekutuan Mahasiswa Kristen Antar Universitas (Perkantas) menunjukkan intensi untuk berperilaku prososial karena adanya kesamaan antara dirinya dengan individu lain sebagai ciptaan Tuhan yang mulia untuk saling menjaga dan berbuat baik bagi sesama.

Hal ini senada dengan penelitian Carlo dan Walker (2007) yang mengungkapkan bahwa nilai-nilai diri yang dimiliki seseorang, seperti kejujuran, kebaikan, dan keadilan dapat memediasi peranan orang tua dan teman sebaya agar dapat berperilaku prososial dalam kehidupannya. Berdasarkan uraian-uraian di atas maka dapat disimpulkan bahwa religiositas dan konformitas teman sebaya secara bersamaan dapat memengaruhi perilaku prososial mahasiswa yang mengikuti Persekutuan Kristen Antar Universitas (Perkantas) Jakarta.

Kemudian, hasil uji komparatif terhadap perbedaan jenis kelamin menunjukkan bahwa mahasiswa perempuan yang mengikuti Persekutuan Kristen Antar Universitas (Perkantas) Jakarta lebih cenderung berperilaku prososial dibandingkan mahasiswa laki-laki. Hasil analisis tersebut sejalan dengan studi Renata dan Parmitasari (2016) yang menyatakan bahwa anak perempuan memiliki orientasi yang lebih besar terhadap kebutuhan dan kesejahteraan orang lain dibandingkan dengan anak laki-laki, sehingga memungkinkan penurunan risiko mereka untuk mengembangkan perilaku yang mengganggu. Sementara itu, Retnaningsih (2005) menyatakan bahwa adanya perbedaan yang signifikan dikarenakan masih kuatnya tuntutan peran gender yang ada di masyarakat terhadap perempuan dan laki-laki. Anak laki-laki seringkali diapresiasi untuk 
berkompetisi dan meningkatkan sikap kompetitif, sedangkan anak perempuan lebih sering membentuk kelompok pertemanan dan bekerja sama.

Selain itu, responden penelitian ini merupakan mahasiswa dengan rentang usia 16-19 tahun, 19-22 tahun, dan 22-25 tahun. Ketiga kelompok usia ini dapat berperilaku prososial dalam kehidupannya sehari-hari apabila memiliki toleransi yang kuat dan mampu menerapkan nilai-nilai ajaran agamanya dalam hal mengasihi sesama umat manusia. Dengan kata lain, perilaku prososial secara umum dapat dilakukan oleh individu dari semua usia. Hal ini menunjukkan bahwa semakin meningkatnya usia bukanlah sebuah jaminan bagi individu untuk menampilkan peningkatan dalam berperilaku prososial. Namun demikian, individu yang matang, bertanggungjawab, dan memiliki kepekaan sosial yang tinggi cenderung lebih mudah untuk berperilaku prososial. Hal ini sejalan dengan studi Agustiani (2009) yang menyatakanbahwa usia dengan perilaku prososial tampak nyata apabila dihubungkan dengan tingkat kemampuan bersosialisasi dan tanggung jawab yang dimiliki individu. Dengan kata lain, individu dengan kemampuan bersosialisasi dan tanggung jawab yang baik cenderung lebih dapat berperilaku prososial.

Berdasarkan uraian diskusi di atas, secara umum penelitian ini telah membuktikan adanya pengaruh religiositas dan konformitas teman sebaya terhadap perilaku prososial. Studi ini memiliki beberapa keterbatasan. Jumlah dan lingkup responden terbatas pada komunitas rohani Kristen, sehingga hasil ini tidak representatif untuk diaplikasikan pada afiliasi keagamaan lain. Selain itu, mengingat penelitian ini dilakukan di komunitas rohani yang mendorong individu untuk dapat berperilaku positif, maka dimungkinkan adanya kecenderungan responden yang merespon instrumen penelitian (kuisioner) berdasarkan kepatutan sosial.

\section{SIMPULAN DAN SARAN}

\section{Simpulan}

Studi ini menunjukkan adanya pengaruh yang signifikan antara religiositas dan konformitas teman sebaya terhadap perilaku prososial mahasiswa yang mengikuti Persekutuan Mahasiswa Kristen Antar Universitas (Perkantas) Jakarta. Secara spesifik, semakin tinggi religiositas dan konformitas mahasiswa dengan teman sebayanya, maka akan semakin tinggi pula perilaku prososialnya. 


\section{Saran Teoretis}

Bagi penelitian selanjutnya, bila hendak melakukan penelitian mengenai perilaku prososial agar dapat memilih variabel-variabel lain yang diduga dapat menjadi faktor-faktor yang memengaruhi perilaku prososial, seperti empati, pola asuh, kecerdasan emosional, dan altruisme, maupun meninjau berdasarkan usia dan gender.

\section{Saran Praktis}

Persekutuan kemahasiswaan berbasis agama diketahui turut menstimulasi perilaku prososial. Oleh karena itu, universitas dapat mendorong mahasiswa untuk turut terlibat aktif dalam perkumpulan keagamaan guna memelihara nilai moral dan budaya prososial di lingkungannya.

\section{REFERENSI}

Agustiani, H. (2009). Psikologi perkembangan, pendekatan ekologi kaitannya dengan konsep diri dan penyesuaian diri pada remaja. Bandung: Refika Adiatmika.

Baron, R. A., \& Byrne, D. (2005). Psikologi sosial (10th ed.). Jakarta: Erlangga.

Carlo, G., \& Hardy, S. A. (2005). Religiosity and prosocial behaviours in adolescence: The mediating role of prosocial values. Journal of Moral Education, 34, 231-249.

Carlo, G., \& Walker, L. M. (2007). Personal values as a mediator between parent and peer expectations and adolescent behaviors. Journal of Family Psychology, 21, 538-541.

Cinthia, R. R., \& Kustanti, E. R. (2017). Hubungan antara konformitas dengan prokrastinasi akademik pada mahasiswa. Jurnal Empati, 6(2), 31-37.

Karvani, A. R., \& Nangoi, P. F. (2013). Hubungan konformitas teman sebaya dan konsep diri dengan kenakalan remaja di Jakarta Selatan (Skripsi tidak dipublikasikan). Universitas Bina Nusantara, Indonesia.

Khoirina, I. (2015). Perbedaan perilaku prososial remaja ditinjau dari gender (Skripsi tidak dipublikasikan). Universitas Islam Negeri Sunan Ampel Surabaya, Indonesia.

King, P. E., \& Furrow, J. L. (2004). Religion as a resource for positive youth development: Religion, social capital, and moral outcomes. Developmental Psychology, 40(5), 703-713. doi: $10.1037 / 0012-1649.40 .5 .703$

Lim, C., \& Putnam, R. D. (2010). Religion, social networks, and life satisfaction. American Sociological Review, 75(6), 914-933. doi: 10.1177/0003122410386686 
Myers, D. G. (1999). Social psychology (6th ed.). New York, NY: McGraw Hill.

Papalia, D. E., Olds, S. W., \& Feldman, R. D. (2013). Human development. Jakarta: Salemba Humanika.

Pertiwi, F. D., \& Masykur, A. M. (2014). Hubungan antara konformitas dengan intensi prososial pada remaja warga binaan pemasyarakatan Lapas Anak Kelas II A Kutoarjo. Jurnal Empati, $3(1), 1-10$.

Pradana, D. A. (2013). Hubungan antara konformitas dengan altruisme (Skripsi tidak dipublikasikan). Universitas Muhammadiyah Surakarta, Indonesia.

Renata, S., \& Parmitasari, D. L. N. (2016). Perilaku prososial pada mahasiswa ditinjau dari jenis kelamin dan tipe kepribadian. Jurnal PSIKODEMENSIA, 15(1), 24-39. doi: 10.24167/psiko.v15i1.590

Retnaningsih. (2005). Peranan kualitas attachment, usia, dan gender pada perilaku prososial. Proceeding Seminar Nasional PESAT, 9-17.

Sears, D. O., Peplau, L.A., Freedman, J. L., \& Taylor, S. E. (1988). Social psychology (6th ed.). Englewood Cliffs, NJ: Prentice Hall.

Sinaga, D. R. (2015). Hubungan antara religiositas dengan perilaku prososial pada mahasiswa program studi bimbingan dan konseling Universitas Kristen Satya Wacana (Skripsi tidak dipublikasikan). Universitas Kristen Satya Wacana, Indonesia.

Suryadi, D. (2009). Hubungan antara konsep diri dan konformitas terhadap perilaku konsumerisme pada remaja akhir dan dewasa awal di Jakarta (Skripsi tidak dipublikasikan). Universitas Tarumanegara, Indonesia.

Wicaksono, R. D. W., \& Andriani, F. (2015). Pengaruh konformitas terhadap intensi perilaku menyontek pada siswa SMAN 12 Surabaya. Jurnal Psikologi Pendidikan dan Perkembangan, 4(2), 140-148.

Zubaidi, A. (2009). Kajian terhadap perkembangan moral generasi muda. Jakarta: Mitra Wacana Media. 